\title{
Mesajul Președintelui SRUMB
}

Dragi colegi ecografiști, membrii sau poate viitori membrii ai Societății Române de Ultrasonografie. Așa cum se obișnuiește la început de An Nou, se face bilanțul realizărilor din anul care a trecut și se concep planuri pentru Noul An. Facem aceasta cu speranța că planurile de viitor vor fi îndeplinite și - dacă au fost bine concepute - vor aduce progres și realizări profesionale și personale în anul care a început.

În 2015 ne-am propus, prin conducerea actuală, ajungerea la o stare de normalitate într-o societate profesională cum este SRUMB. Am dorit ca normalitatea să cuprindă toate domeniile în care societatea noastră poate să acționeze. Am vrut ca societatea să se stabilizeze financiar, ca o primă condiție menită să asigure funcționarea ei prezentă și viitoare. Am reușit acest lucru, chiar și prin ușoara diminuare a numărului de membrii (aveam la sfârșitul lunii decembrie un număr de 256 de membrii cu taxele la zi și un număr de 71 membrii abonați la European Journal of Ultrasound). Nu a fost ușor să atingem echilibrul, având în vedere că, în pofida succesului de care s-au bucurat cele două evenimente știintifice naționale majore în domeniul ecografiei în 2015 - conferința națională a SRUMB și scoala de vară de la Constanța - exercitiul financiar a adus beneficii mici pentru SRUMB. Dealtfel, sumele au fost utilizate rapid, în principal pentru editarea numerelor din revista de ultrasonografie a societății noastre.
Dacă financiar am obținut un echilibru suficient pentru a funcționa ca societate, activitatea profesională științifică a înregistrat progrese constante, materializate în principal prin creșterea evidentă a calității revistei de ultrasonografie, editată sub auspiciile SRUMB. Este în principal meritul Comitetului de redacție în frunte cu Editorul Șef, dar care s-au bucurat de tot sprijinul din partea Comitetului director al SRUMB precum și din partea membrilor societății. Aceștia au trimis materiale de calitate pentru publicare, recenzii, articole originale, alături de alți membrii ai unor societăți similare, europene și internaționale.

Chiar dacă SRUMB nu a patronat direct unele cursuri de formare sau work-shopuri, acestea s-au desfașurat pe parcursul anului trecut în diferite locații din țară, în principal în centre universitare sau centre de formare în ultrasonografie, fiind susținute de membrii societății noastre și mai ales de membrii echipei Comitetului Director. Informații despre astfel de manifestări ultrasonografice cu caracter de educație medicală continuă sau cursuri pentru obținerea de atestate în diferite competente ultrasonografice, au fost și vor fi publicate periodic pe site-ul societății noastre.

Nu în ultimul rând menționăm faptul că buna desfășurare a activităților în societatea noastră a fost posibilă prin munca

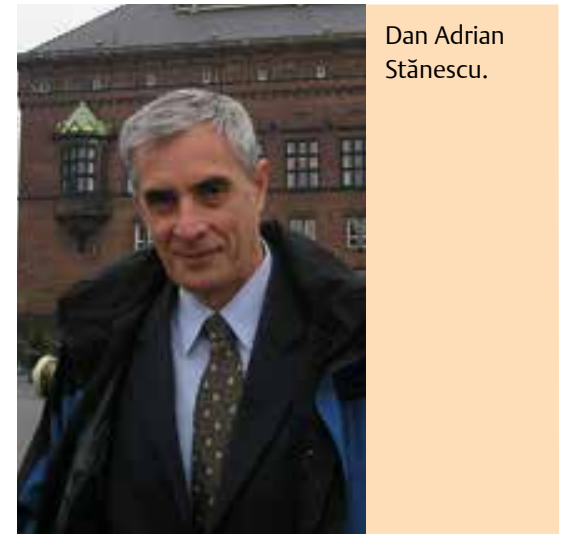

dedicată a secretariatului societății, care a asigurat o excelentă comunicare între membrii conducerii executive, cu membrii Comitetului Director și membrii societății, între colaboratori și personalul tehnic, înlesnind informarea rapidă, luarea unor decizii și punerea lor în practică.

Ce ne dorim în 2016? În principal să continuăm și să îmbunătațim ce am început în 2015.

Într-un număr anterior am făcut apel la factorii guvernamentali, menționând lipsa de achiziții, de mai mulți ani, la nivel național, a echipamentelor moderne de ultrasonografie. Reluăm acest apel la început de an, către o echipă guvernamentală nouă, în care ne punem mari sperante. LA MULȚI ANI !

Dan Adrian Stănescu. MD, Ph.D Președinte executiv SRUMB 